\title{
Code-Mixing as a Promotion Strategy in Shopping Centres
}

\author{
${ }^{1}$ Novia Sophia Farida \\ ${ }^{1}$ Mataram University, Mataram, Indonesia \\ noviasophia@gmail.com
}

\begin{tabular}{|c|c|}
\hline Article Info & Abstract \\
\hline $\begin{array}{l}\text { Article History } \\
\text { Received: July 12, } 2018 \\
\text { Accepted: September 30, } \\
2018 \\
\text { Keywords } \\
\text { Code-Switching And Code- } \\
\text { Mixing; Business Strategy; } \\
\text { Communication Strategy; } \\
\text { Promotion The Products }\end{array}$ & $\begin{array}{l}\text { The aim of this study is to investigate the goals of Code-Switching and Code- } \\
\text { Mixing and how it is used in a communicative strategy among the stand } \\
\text { banners in Lombok Epicentrum Mall (LEM). Data were collected by } \\
\text { documenting with pictures of stand banners at several outlets in LEM. The } \\
\text { method used in analyzing the data is qualitative in approach by identifying, } \\
\text { classifying, describing and explaining the code-switching and the code } \\
\text { mixing data in the corpus and how they have been used to promote the } \\
\text { products sold at the stores. The result shows that the purposes of using Code- } \\
\text { Switching and Code-Mixing as a communication strategy in their promotion } \\
\text { and it also shows that code mixing is more dominant than code switching. } \\
\text { The advertisers mix-match the languages that they use with English and } \\
\text { Bahasa Indonesia because they assume that these practices are the right } \\
\text { ones and matching Indonesian words into English makes it sound cooler } \\
\text { instead of using Bahasa Indonesia. This indicates that English signifies a high } \\
\text { culture and class status while Indonesian is inferior in status. In fact, being } \\
\text { commonly used in numerous stand banners for a long period of time, the } \\
\text { mixing use of Indonesian and English as well as matching the sounds in the } \\
\text { languages have been very common and accepted in Indonesian discourse } \\
\text { practices. Therefore, the implication that they communicate their business } \\
\text { strategy of promotion their products by using CS and CM is to inform and } \\
\text { attract the customers that they are in a higher level or class, thus, it acquires } \\
\text { them to communicate or promoted like so. }\end{array}$ \\
\hline $\begin{array}{l}\text { Support by: } \\
\text { doi) Crossref }\end{array}$ & This is an open access article under the CC-BY-SA license \\
\hline
\end{tabular}

\section{INTRODUCTION}

Language is one of the cultural products of a nation. With language people can know the culture of others. The variety of languages that often appear is usually influenced by social culture that exists in society. In a state of bilingualism, there will often be people changing the language or the variety of languages: it depends on the circumstances or needs of the language. Code-switching is an event of change of language, when one diverts a language in another language or a variety of languages in a language act without anything in the language situation. As Myers-Scotton stated that CS as a speech phenomenon initially did not receive much attention from researchers on bilingualism. It was merely regarded as interference in the speech of bilinguals (Myers-Scotton, 1993a: 47).

Much if not all of the earliest linguistic research on mixed-language texts was actually done on representations of speech embedded within texts belonging to a written genre. This line of research began with an important study by Birgit Stolt (1964) on the German-Latin mixing in Luther's Tischreden, Luther's mealtime conversations recorded by his followers who dined with him. Early studies usually treated the written texts as a source of evidence about spoken practices-the only available evidence, in the 
case of texts predating modern sound recording technology-and tended to be concerned with the kinds of syntactic and pragmatic issues which also preoccupied researchers of spoken code-switching at the time. For example, Timm's (1978) study of French-Russian code-switching dialogue in Tolstoy's novel War and Peace deals with syntactic on strains on switching, using the vocabulary of phrase structure analysis. For most of the earlier researchers, the written data was considered a secondary source, complementary to spoken data but possibly somewhat less reliable as an indication of bilingual behavior. Such representations of speech were, of course, likely to be stylized to some extent and affected in poorly understood ways by the shift of modality from spoken to written. The focus on spoken data as the primary object of interest is also seen in more recent research; however, as knowledge about spoken code-switching practices has expanded and become more robust and theoretically informed, researchers have begun to carry out studies comparing documented spoken practices and their representations in texts of different sorts. For example, Moyer (1998) studied a humorous newspaper column in Gibraltar and compared the Spanish-English codeswitching represented there with audio-recorded data. Callahan (2004) makes an extensive study of Spanish-English dialogue in prose fiction, using the Matrix Language Frame model developed by Carol Myers-Scotton (1993). Callahan concludes $(2004,2)$ that 'the successful application to a written corpus of a model developed for speech validates the use of written data, and shows that written code switching is not inauthentic.' Thus, gradually, written data has become more 'respectable' as data in its own right in structurally-oriented code-switching research.

Perhaps no other element of international business is so often noted as a barrier to effective communication than differences in language. Language is neither the only nor even the most important communication impediment in cross-cultural encounters. Nevertheless, it remains the most obvious hurdle that international business communicators are likely to face. The reason for language being such a significant obstacle in international as well as domestic cross-cultural business is, according to Victor (1992), because it is so fundamental. Without a shared language, direct communication is at best filtered through at third party and at worst altogether impossible. If, in the contemporary knowledge-based economy, corporations strive to create a culture of learning and knowledge within their organizations, then they need to recognize the fact that the essential skills of language form the basis of organizational human capital (Dhir \& Goke-Pariola, 2002).

One of the reasons why business managers until recently have been reluctant to acknowledge language to the extent that they introduce a language management strategy, is probably partially because of the costs related to such an investment. By creating situations in which language would facilitate efficiency and result in synergistic interactions among individuals, the business manager may use language to create economic value, by the efficient and effective knowledge management for gaining competitive advantage through intellectual capital.

The key to understanding the linguistic market is to understand that it is "where" power relations are expressed. Those controlling the linguistic varieties that are most valued have more power or more symbolic capital in this market than others controlling varieties of lesser value in the market. So, the market shapes the symbolic value of different ways of speaking; therefore, speakers of different language varieties possess different quantities of linguistic or symbolic capital. The value of a language variety as an "asset" is related to other forms of capital associated with the specific variety in question (economic capital, cultural capital). Altogether, these forms of capital define 
the place of an individual in social "space" (i.e., the person who speaks that specific variety) Myers-Scotton (2005, p 114).

\section{METHOD}

In this study, I used a qualitative method in analyzing the code-switching and codemixing as communication strategy of promotion in Lombok Epicentrum Mall. I explained the quality of the object empirically. The object of this study is not the number of people or individual, but a literary and linguistic work, that is why the static method is not a proper method in analyzing the data in this study. I described the purposes of code-switching and code-mixing as a strategy of promotion among outlets' stand banner and how they are used in a communicative strategy of promotion of outlets' stand banner in Lombok Epicentrum Mall.

The data of this study are taken from several stand banners in Lombok Epicentrum Mall outlets. There were twenty-eight (28) photos of stand banners that I collected to be the population of data, but I decided to pick nine (9) samples of them. The technique to collect the data was listening and note taking. Listening that is meant here listen to the language used was written technique. Meanwhile, the note taking technique is meant here to record some forms that are considered relevant or can be incorporated into the research of the language used in writing to analyze the code-switching and code-mixing on the stand banners, writer uses library research. The writer found the books, articles, and the websites, which related to the study of code-switching and code-mixing.

After collected the data and observed the information from the stand banners, the validity of the data on the research should be tested, and it uses triangulation theory because in analyzing the data, I use the perspective of more than one theory to discuss the issues of study. More than one perspective will be used to analyze and describe completer and more thorough conclusion. Data analysis in this study uses the method of intralingual pads and the method of extra-lingual. Inverse intralingual method is the method of analysis by way of comparing the elements that are lingual (Mahsun, 2005). The method of extra-lingual padding is used to analyze elements that are extra-lingual (Mahsun, 2005).

\section{RESULT}

In this part, I would like to present the findings in communication strategy of promotion in several stand banners in Lombok Epicentrum Mall's outlets. It talks about the purposes of code-switching and code-mixing among the outlets' stand banners and how they are used in a communicative strategy of promotion. After observing and analyzing the data based on the methodology, I only found two samples of data which contain code-switching in their stand banners. But there were seven samples which contain code-mixing.

\section{Code-switching}

According to Myers-Scotton (2006, p. 161) code-switching is the use of two language varieties in the same conversation. It can occur between speakers, or between sentences in the same speaker's turn, or within a sentence.

\section{Data 1: "Harga belum termasuk PPN Service \& Tax"}

The first data that was observed above shows code-switching in use which is the words "PPN Service \& $\boldsymbol{T a x}$ " are two languages with same meaning. PPN is Bahasa Indonesia which means Value Added Tax (VAT) or Goods and Services Tax (GST) in international language. The words PPN Service \& Tax shows the purposes of the owner 
or the author of the company is to keep local and interlocal people understand or aware the intentions of the restaurant owner-considering this stand banner is a banner to promote a new restaurant open.

Furthermore, the use of code-switching in this stand banner do not generally considered as part of the language proper. Therefore, the communicative strategy of promotion in this stand banner is only to fulfill the owner intentions to their customers in case they are understood or not.

Data 2:

$\begin{array}{ll}\text { - } & \text { Daftar Harga (Price List) } \\ \text { - } & \text { Perawatan (Treatment) } \\ \text { - } & \text { Manicure/Pedicure + Kutek Halal (Halal Polish) } \\ \text { - } \quad \text { SPA Tangan Kaki // SPA for Arms Food (Cuccio Opi) } \\ \text { - } \quad \text { Nail Art dengan Kutek Kuku // Polish Nail Art (Polkadot \& Stripes only) } \\ \text { - } \quad \text { Get Nail Art Gradasi }\end{array}$

In the second cluster of data, I prefer to pick six samples of fifty-five population (6/55) instead (data attached), because each of the language have the same format of writing - Bahasa Indonesia to English or English to Bahasa Indonesia-. The second data above shows the code-switching in use, it obviously indicates how the owner of Olive Nail House - name of the outlet - wanted everyone from different classes to get in and try to use the services that they offer.

In addition, the communicative strategy they used in their stand banner is considered as part of language in code-switching uses, because it is including to switching as a marked choice, meaning that the speaker has departed from the unmarked choice to signal a desire to negotiate a new set of rights and obligations.

\section{Code-mixing}

According to Wardhaugh (1992: 106 and Bokamba, 1988: 24, in Moodley, 2001: 9), they define code-mixing as: '... the deliberate mixing of various linguistic units such as affixes, words, phrases and clauses from two (or more) languages within the same sentence, in the course of a single utterance, without an associated change in topic'.

Data 3: "Lapar? Delivery masakan nusantara aja"

The third data above was called as code-mixing, and if it translated into English it could become "Are you Hungry? Nusantara Cuisine is the best choice for you to delivery order". The word delivery in Bahasa Indonesia means pengiriman. Therefore, if it completely using Bahasa Indonesia, it does not generally consider as part of language even in Bahasa Indonesia. It shows how forcefully the owner of restaurant considering this stand banner is a banner of restaurant - to choose the match word instead to make it looks like in high class restaurant.

Hence, the use of code-mixing in this stand banner do not generally considered as a part of the language proper. Thus, communication strategy of promotion in this stand banner is only to make their restaurant looks like the high-class restaurant compare to others.

Data 4:

- $\quad$ Khusus untuk tiket yang expired 31 Desember 2017

- Untuk keterangan lebih lanjut hubungi staff kami

The forth data shows the code-mixing in stand banner of arena games outlet called Timezone. Code-mixing here marked in words of expired and staff. If it completely using Bahasa Indonesia, it considers as part of perfect language of Bahasa Indonesia. Thus, the purposes of the owner in code-mixing two languages are because these two English words are generally in use by Indonesian people instead of to be looking cool. 
Afterwards, the code-mixing in this stand banner worth be said as part of the language proper because it is generally used as communication among people of Indonesia especially in strategy of promotion.

Data 5: "Lebih banyak Reward dan Benefit"

The fifth data were taken from stand banner of Telkomsel service center; the data show the code-mixing in use. The words Reward and Benefit that they mix-match in their stand banner simply and solely to sound as high class rather than using Bahasa Indonesia. Why did I say like that? Because, even they use Bahasa Indonesia, it completely called as the perfect language of Bahasa Indonesia. Instead of using English to sounds cool than using Bahasa Indonesia. Hence, the use of code-mixing in this data was considered as part of language proper. Thus, communicative strategy of promotion in this stand banner reaches the customers attention because these two words are generally used as communication among people of Indonesia.

Data 6: "Pilihan Lebih, Cash back Lebih"

The data above show the code-mixing in stand banner of service center of Xl-Axiata which is one of brand name of a GSM and UMTS Mobile phone network operator which operates in Indonesia. The word cash back above in Bahasa Indonesia is uang kembali which means cash refund in English. However, it is particularly a good language choice. It also sounds like they have to use this word instead of Bahasa Indonesia, because this word is generally used in market language use. Thus, Indonesian people are already accustomed in used this word instead the mother tongue.

Furthermore, the use of code-mixing in this stand banner generally considered as part of language proper. Thus, the communication strategy of promotion language in this stand banner in addition to get customers attention, it also has the hidden meaning of their communication in business strategy.

Data 7:

\section{- Book \\ Service barber kapan aja \\ Promo \\ Gak ketinggalan promo yang ada \\ - Reward \\ Kumpulin point dan redeem reward dengan mudah}

The seventh data above show lots of code-mixing. The word book here means order or reserve, which in Bahasa Indonesia commonly used menerima pesanan. However, it barely used today by people zaman now. Again, they used that word instead to sounds it cool. Then word service means the action of helping or doing work for someone, but in Bahasa habitually used layanan. And barber is a person who cuts hair, especially men's, and shaves or trims beards as an occupation, yet it generally called as tukang cukur in Bahasa. Therefore, if it completely combines they into Bahasa and they become menerima layanan jasa tukang cukur. It obviously that they think those words in Bahasa sounds really not elegant then they preferred to use English instead.

Hence, the communicative strategy of this stand banner promotion language is generally Bahasa Indonesia English (English that in Bahasa structure). It could be perfectly Bahasa structure if they not code-mixing their language. Therefore, the communication strategy of promotion in this stand banner is not generally as part of language proper.

Data 8: "Invite Ichikuma di WA/LINE grup kamu"

The eighth data show its code-mixing also, the translation of the data was Invite Ichikuma in Whatsapp/LINE of yours. This stand banner's owner engaged the customer into their social media account in order for its customers to get a variety of promos that 
they offer through social media. The word invite is generally used by among Indonesian people, then the owner explicitly using this word in order to get customers attention and understanding.

Furthermore, this code-mixing is officially accepted by community in communication strategy of promotion, but not by linguist. Because invite is not the mother tongue of Bahasa Indonesia. Therefore, the communication strategy of promotion in this stand banner is not generally as part of language proper.

Data 9: "Top Up Lebih Cepat di Banyak Tempat"

The last data was also showing the code-mixing in use of stand banner which is the application promotion named OVO. The words Top up are usually used by citizen of Indonesia, certainly by people who have called themselves as the high class in term of economical. And it menambah (saldo) in Bahasa. They used words top up instead of isi ulang in Bahasa. Therefore, the purposes of the owner of this application are aimed at people of a high class.

Hence, the communication strategy of promotion in stand banner not only for the outlets which is they stands for, but also for certain application in order to promote their products. Therefore, using top up words are not properly in language use if it by linguists' view. However, it is warrantable if it used by citizen as daily conversation, but instead must sacrifice the mother tongue.

\section{CONCLUTION}

After analyzed and observed the whole data (samples), I can take the conclusion of this research, the code-switching and code-mixing of the language in use in stand banners of ten samples' outlets on average do not considered have the parts of the language proper. Instead, they - refer to the owners of outlets - used English in Bahasa Indonesia. Therefore, instead of getting the right language pattern, the language they have used actually sounds weird when it is viewed from linguistic perspective.

\section{REFERENCE}

[1] Aitchison, J., and Lewis, D.M. 2004. New Media Language. Taylor and Francis eLibrary. Canada. USA

[2] Cf. Kotler, P., Marketing Management 7th ed. (Englewood Cliffs: Prentice Hall 1991).

[3] Coupland, Nikolas. 2010. The Handbook of Language and Globalization. Wiley Blackwell. United Kingdom.

[4] Fill, Chris and Jamieson, Barbara. 2006. Marketing Communications. Great Britain

[5] Mahsun. 2005. Metodologi Penelitian Bahasa: Tahapan, Strategi, Metode, dan Tekniknya. Jakarta: PT. Raja Grafindo Persada.

[6] Myers, C., and Scotton. 20016. Multiple Voices: An Introduction to Bilingualism. Blackwell Publishing. Australia

[7] Oxford Advanced Learner's Dictionary. Eighth Edition.

[8] Routledge. 2012. Language mixing and code-switching in writing: approaches to mixed language written discourse. Edited by Mark Sebba, Shahrzad Mahootian, and Carla Jonsson. University of Birmingham, UK.

[9] Sebba, M. 2007. Spelling and Society: The Culture and Politics of Orthography around the World. Cambridge: Cambridge University Press.

[10] Woolard, Kathryn A. (1989) Double Talk, Bilingualism and the Politics of Ethnicity in Catalonia. Stanford, CA: Stanford University Press. 
[11] Rhodes, J. 2013. On methods: What's the Difference between Qualitative and Quantitative Approaches? [Online.] Available at www.theChronicleof Evidence-Based Mentoring.htm [accessed 23/12/17]

[12] http://en.wikipedia.org/wiki/Code-switching. [Accessed 21/12/17] 